\title{
EFEK STOKASTIK RADIASI SINAR-X DENTAL PADA IBU HAMIL DAN JANIN
}

Niluh Ringga Woroprobosari*

\begin{tabular}{c}
\hline Keywords: \\
x-ray radiation, pregnant \\
women, fetuses, \\
teratogenic. \\
\end{tabular}

\section{ABSTRACT}

Background: Dental radiographic examination is one of the most frequent radiological examinations carried out. X-rays in dental radiography is a shortwave electromagnetic rays that cause ionization reaction to any biological material in its path. The purpose of this article is to give an overview of stochastic effects in general as well as to pregnant women and fetuses in particular.

Discussion: lonizing radiation, such as $\mathrm{X}$-ray radiation, is potentially teratogenic. Safe dose has not been well defined, although there has been approved dosing limits. Gestational age most vulnerable is the end of week 2 to 8 weeks post-conception. If the much needed radiographs of a woman who is pregnant, then the X-ray exposure will be directed mostly to the head and neck area.

Conclusion: Therefore, the application of the principle of ALARA (As Low As Reasonably Achievable) as well as good protection, including instrument control, protection of the room, the cumulative exposure dose control, and the use of apron throughout the process, is noteworthy. Such protection, especially for pregnant women and fetuses.

\section{PENDAHULUAN}

Radiasi pengion dalam bentuk sinar- $x$ dan sinar-y merupakan sinar elektromagnetik gelombang pendek. Foton berenergi rendah pada sinar- $x$ dan foton berenergi tinggi pada sinar-y dapat mengubah struktur normal dari sel hidup baik secara langsung maupun tidak langsung. Mekanisme langsung melibatkan gangguan struktur atom untuk menghasilkan senyawa terionisasi dan elektron bebas. Mekanisme tidak langsung melibatkan radiolisis air dan pembentukan radikal bebas ${ }^{1}$.

Mekanisme tidak langsung adalah pembentukan radikal hidrogen dan hidroksil bebas yang dihasilkan oleh radiasi pada air, kemudian berinteraksi dengan molekul organik. Interaksi hidrogen dan radikal bebas hidroksil dengan molekul organik menghasilkan pembentukan radikal bebas organik. Sekitar dua pertiga dari kerusakan biologis akibat radiasi dihasilkan dari efek tidak langsung tersebut. Reaksi pembentukan radikal bebas organik tak langsung adalah sebagai berikut:

$$
\begin{aligned}
& \mathrm{RH}+\mathrm{OH}^{*} \rightarrow \mathrm{R}^{*}+\mathrm{H}_{2} \mathrm{O} \\
& \mathrm{RH}+\mathrm{H}^{*} \rightarrow \mathrm{R}^{*}+\mathrm{H}_{2}
\end{aligned}
$$

Radikal bebas $\mathrm{OH}^{+}$lebih berperan dalam menyebabkan kerusakan tersebut. Radikal bebas organik bersifat tidak stabil dan akan terus berubah hingga menjadi stabil. Molekul yang berubah tersebut memiliki sifat kimiawi dan biologis yang berbeda dari molekul aslinya 2 .

Pemeriksaan radiografi gigi adalah salah satu studi radiologi paling sering dilakukan. Sebuah survei tahun 1999 di Jepang

* Departemen Radiologi, Fakultas Kedokteran Gigi Universitas Islam Sultan Agung (Unissula) Semarang Korespondensi: niluh_antares@yahoo.com 
memperkirakan bahwa dokter gigi membuat 82 juta radiografi intraoral dan lebih dari 12 juta radiografi panoramik setiap tahun ${ }^{3}$. Dosis efektif yang diberikan kepada pasien tiap radiografi adalah dosis rendah, tetapi dosis kolektif besarnya cukup signifikan karena jumlah besar radiografi dibuat.

\section{KARAKTERISTIK SINAR-X DENTAL}

Sinar-x dental merupakan pancaran gelombang elektromagnetik dengan panjang gelombang yang sangat pendek, yaitu 1/10.000 dari panjang gelombang sinar tampak. Wilhelm Conrad Roentgen adalah fisikawan yang pertama kali menemukan sinar-x pada tahun 1895.4 Jenis sinar elektromagnetik ini ditemukan saat bereksperimen dengan sinar katoda. Sinar ini memiliki beberapa sifat fisik, antara lain:

1. Sinar-x dental mampu menembus bahan dengan daya tembus yang besar. Semakin tinggi tegangan tabung yang digunakan (besarnya KV), maka akan semakin besar daya tembusnya. Daya tembus juga akan semakin besar bila melewati suatu benda dengan berat atom atau kepadatan yang rendah.

2. Sinar-x dental dapat menimbulkan radiasi sekunder, yaitu dari tebarannya ke segala arah saat melalui suatu bahan/ zat, sehingga akan mengakibatkan gambaran radiografi dan pada film akan tampak pengaburan kelabu secara menyeluruh. Grid digunakan untuk mengurangi efek radiasi hambur tersebut. Grid adalah potongan timah tipis sejajar yang diletakkan di antara subjek dan film rontgen.

3. Sinar-x dental dalam radiografi yang diserap oleh suatu bahan sesuai dengan berat atom atau kepadatan bahan tersebut. Semakin tinggi kepadatan atau berat atomnya, maka semakin besar pula penyerapannya.

4. Sinar-x dental dapat menghitamkan emulsi film (perak-bromida) setelah diproses secara kimiawi di kamar gelap.

5. Sinar-x dental dapat menyebabkan bahan tertentu memendarkan cahaya (luminisensi), seperti kalsium-tungstat atau zinc-sulfide.

6. Sinar-x dental dapat menyebabkan ionisasi partikel-partikel suatu bahan/zat saat dia melaluinya. Hal ini merupakan efek primer dari sinar-x dental.

7. Sinar-x dental dapat menyebabkan perubahan biologis pada jaringan, dan hal ini dimanfaatkan dalam bidang radioterapi ${ }^{5}$.

\section{RADIOBIOLOGI SINAR-X DENTAL}

Interaksi awal antara radiasi pengion dan suatu bahan terjadi pada tingkat elektron dalam 10-13 detik pertama setelah paparan. Perubahan ini mengakibatkan modifikasi molekul biologis dalam hitungan detik hingga jam berikutnya. Pada prosesnya, perubahan molekul dapat menyebabkan perubahan dalam sel dan organisme yang bertahan selama berjam-jam, beberapa dekade, dan bahkan mungkin berlanjut ke generasi-generasi berikutnya. Perubahan ini dapat menyebabkan cedera atau kematian ${ }^{2}$.

Efek samping dari radiasi dikelompokkan 
menjadi dua kategori, yaitu efek deterministik dan efek stokastik. Efek deterministik didasarkan pada kematian sel dan memiliki hubungan dengan dosis ambang. Apabila dosis yang diberikn berada di bawah ambang batas maka tidak muncul efek klinis. Apabila dosis paparan yang diberikan berada di atas ambang batas, maka keparahan kerusakan meningkat sesuai dosisnya. Sedangkan efek stokastik adalah efek yang timbul tanpa dipengaruhi besar dosis paparan ${ }^{3,6}$.

\section{EFEK STOKASTIK RADIASI SINAR-X DENTAL}

Efek stokastik adalah efek lain yang bisa terjadi. Perkembangan kerusakan akibat efek stokastik muncul secara acak dan bergantung pada probabilitas struktur radiosensitif pada kepala dan leher. Struktur yang bersifat radiosensitif antara lain kelenjar tiroid, kelenjar ludah, sumsum tulang (leukemia) dan otak. Selain itu embrio/fetus juga bersifat radiosensitif, dan kehamilan periode tertentu rawan terjadi resiko kanker apabila terpapar radiasi ${ }^{7}$.

\section{a. Stokatik Somatik}

Efek stokastik somatik radiasi sinar- $x$ dental contohnya adalah jenis leukemia dan tumor tertentu. Efek kerusakan tersebut terjadi setiap tubuh terkena paparan dosis radiasi pada dosis berapapun. Paparan pada gigi secara khusus dikaitkan dengan meningioma, tumor kelenjar ludah dan tumor tiroid ${ }^{8,6}$. Studi yang telah dilakukan belum memungkin untuk menetapkan dosis yang benar-benar aman. yaitu dosis batas yang apabila paparan di bawah dosis tersebut efek stokastik tidak akan terjadi. Oleh karena itu diasumsikan bahwa tidak ada dosis ambang pada efek stokastik, dan bahwa setiap paparan radiasi pengion disertai dengan kemungkinan menginduksi efek stokastik. Semakin rendah dosis radiasi, semakin rendah kemungkinan kerusakan sel. Namun, tingkat keparahan kerusakan tidak berhubungan dengan ukuran dosis yang diberikan ${ }^{9}$.

Pencitraan gigi konvensional tidak pernah menyebabkan efek deterministik. Akan tetapi efek stokastik akibat kerusakan DNA dapat terjadi. Pada tingkat yang jauh lebih kecil, dapat terjadi kerusakan genetik. Paparan radiasi dental dapat beresiko menyebabkan kanker dan leukemia. Hal tersebut disebabkan mutasi DNA dan sifatnya diturunkan ${ }^{10}$.

\section{b. Stokastik Genetik}

Mutasi dapat disebabkan oleh faktor eksternal atau terjadi secara spontan. Mutasi dan kerusakan kromosom kemungkinan diakibatkan oleh ketidakmampuan DNA untuk memperbaiki diri dan/atau gen pengontrol kehilangan kendali proses proliferasi dan diferensiasi. Hal inilah penyebab terjadinya keganasan 10,11. Radiasi sinar-x merupakan salah satu faktor eksternal penyebab yang potensial. Radiasi dosis kecil yaitu 10 - 100 mSv, meningkatkan laju latar kerusakan DNA sekitar $1 \%$ yang terjadi secara alamiah ${ }^{4}$.

Radiasi pada organ reproduksi dapat merusak DNA dari sperma atau sel telur. Hal ini dapat menyebabkan kelainan kongenital pada keturunan dari orang yang terpapar radiasi tersebut. Wanita hamil yang telah menjalani prosedur radiodiagnostik memiliki perkiraan resiko teratogenik yang tinggi (beresiko terjadi malformasi utama sebesar 25,5\%). Sebaliknya, 
wanita yang tidak mengalami prosedur radiodiagnostik memiliki perkiraan yang lebih rendah untuk terjadi resiko teratogenik $(15,7 \%)$ 1.

Meskipun demikian tidak ada kepastian bahwa efek ini akan terjadi, sehingga semua efek genetik digambarkan sebagai stokastik. Hubungan sebab-akibat munculnya efek ini sulit untuk dibuktikan. Radiasi pengion memiliki potensi untuk menyebabkan kerusakan genetik, tetapi belum terdapat data studi pada manusia yang menunjukkan bukti meyakinkan dari hubungan langsung dengan radiasi. Perkiraan resiko telah didasarkan terutama pada percobaan dengan mencit. Paparan dosis 0,5-1,0 Sv pada gonad diperkirakan mengakibatkan mutasi spontan meningkat dua kali lipat. Akan tetapi, hal itu bukanlah tidak mungkin karena diasumsikan bahwa tidak ada dosis ambang pada efek stokastik ${ }^{9}$.

\section{PERLINDUNGAN TERHADAP RADIASI SINAR-X DENTAL}

Perlindungan terhadap efek radiasi ionisasi sinar-x perlu diberikan pada pasien dan personel kesehatan yang terpapar. Ada tiga prinsip dalam proteksi radiasi. Prinsip tersebut juga bermakna kontrol dan pengawasan harus selalu dilakukan pada kualitas diagnostik dan resiko yang berhubungan dengan radiasi. Ketiga prinsip proteksi tersebut adalah sebagai berikut: (Gogos et al., 2002; White \& Pharoah, 2009)

1. Prinsip pertama adalah prinsip justifikasi. Prinsip ini mewajibkan dokter gigi untuk membandingkan maanfaat yang diperoleh dan resiko bahaya yang diterima dalam membuat radiografi gigi. Dokter gigi harus mengidentifikasi situasi di mana paparan diagnostik memberi manfaat kepada pasien lebih besar daripada risiko bahaya yang akan diterima. Pengaruh prinsip ini adalah pemilihan secara tepat pasien seperti apa yang memerlukan pemeriksaan radiografi serta jenis pemeriksaan radiografi yang dibutuhkan.

Contohnya untuk pemeriksaan penunjang karies dan periodontitis lokal cukup dilakukan radiografi perapikal, sedangkan untuk pemeriksaan TMJ awal maupun penyakit periodontal yang sifatnya generalized dapat menggunakan radiografi panoramik. Pertimbangan khusus juga diperlukan dalam pemilihan pasien, misalnya pasien dalam keadaan hamil maupun pasien yang dalam perawatan radioterapi.

2. Prinsip ke dua adalah prinsip optimasi. Prinsip ini menyatakan bahwa dokter gigi harus menggunakan segala cara untuk mengurangi paparan yang tidak perlu kepada pasien mereka dan diri mereka sendiri. Filosofi proteksi radiasi sering disebut sebagai prinsip ALARA (serendah mungkin yang bisa dicapai). ALARA menyatakan bahwa eksposur radiasi pengion harus dijaga serendah mungkin yang bisa dicapai tetapi tetap mampu memberikan gambara radiografi yang representatif, dengan turut mempertimbangkan faktor ekonomi dan sosial.

Optimasi meliputi pemilihan alat, pemilihan tehnik, pengoperasian alat, pemrosesan dan pembacaan gambaran radiografi. Contoh penerapan prinsip 
optimasi adalah dengan mengatur jarak cone beam ke kulit, semakin jauh jaraknya maka dosis yang diterima dapat semakin berkurang (30-45\%). Penerapan prinsi optimasi juga dapat dilakukan dengan pemakaian apron timbal $(\mathrm{Pb})$ yang dilengkapi thyroid collar, karena kelenjar thyroid adalah struktur yang bersifat radiosensitif.

3. Prinsip ke tiga adalah bahwa pembatasan dosis.

Batas dosis yang digunakan pada eksposur pekerja dan masyarakat untuk memastikan bahwa tidak ada individu yang terkena dosis sangat tinggi. Batas dosis tidak digunakan pada individu yang terpapar untuk tujuan diagnostik atau terapeutik. Dokter gigi di setiap fasilitas bertanggung jawab untuk desain dan pelaksanaan program proteksi radiasi.

Posisi pengambilan foto yang aman adalah di luar radius $2 \mathrm{~m} \mathrm{(} \pm 6$ feet) dari pasien dengan cakupan sudut 90-135 derajat dari beam (sumber radiasi). Hanya pasien saja yang boleh berada pada area yang terkena radiasi pada pengambilan foto intraoral, kecuali terdapat instruksi khusus. Pengukuraan beban kerja juga harus dilakukan, dengan tidak melakukan foto lebih dari 100 foto intraoral dan 50 panoramik tiap minggunya. Aturan untuk dokter dan staf tersebut perlu diketahui dan diterapkan oleh tiap personel, demi kesehatan masing-masing ${ }^{12}$.

Fasilitas radiografi gigi harus dirancang dan dibangun untuk memenuhi kebutuhan perisai minimal dariBAPETEN (Badan Pengawas Tenaga Nuklir) dan
ICRP (International Commission on Radiological Protection). Hal ini akan memerlukan konsultasi dengan ahli yang berkompeten. Rekomendasi ini menyatakan bahwa dinding harus memiliki kepadatan atau ketebalan cukup agar mampu melindungi individu non pekerja dari paparan radiasi (misalnya, masyarakat yang bekerja atau tinggal dekat dengan fasilitas radiografi). Batas paparan tidak lebih besar dari 100 mGy per minggu ${ }^{2}$.

\section{DISKUSI}

Radiasi pengion, seperti radiasi oleh sinar-X, bersifat potensial teratogenik. Dosis aman belum terdefinisikan dengan jelas, walaupun sudah ada batas dosis yang disepakati. Oleh karena itu efek dari paparan selama kehamilan perlu dievaluasi untuk mempertimbangkan dosis yang diserap oleh janin ${ }^{13}$.

Embrio dan janin sangat sensitif terhadap radiasi pengion, dan konsekuensi perkembangan bisa sangat serius. Ini dapat bersifat teratogenik, mutagenik, atau karsinogenik. Seperti teratogen hampir semua diketahui, dosis radiasi pengion adalah salah satu faktor penentu toksisitas reproduksi dalam perkembangan embrio / janin. Meskipun embrio dan janin dilindungi sampai taraf tertentu oleh rahim, dosis radiasi cenderung lebih rendah dibandingkan dengan yang ibu terkena. Berbagai penelitian telah menetapkan dosis yang paling umum digunakan prosedur diagnostik dan terapi untuk embrio dan janin. Konsensus saat ini adalah bahwa paparan radiasi dari $<5$ rad selama kehamilan tidak berhubungan dengan peningkatan risiko 
malformasi ${ }^{14}$.

Pembatasan dosis secara ketat mampu menghidarkan janin dari efek deterministik, tetapi belum tentu dapat mengeliminasi efek stokastik yang mungkin terjadi. Efek stokastik terjadi beberapa saat setelah paparan, dan terdiri dari kerusakan materi nukleus dalam sel yang dapat menyebabkan kanker akibat radiasi atau mutasi yang dapat diturunkan kepada keturunan individu yang terpapar.

Efek radiasi pengion pada kehamilan juga tergantung pada usia kehamilan pada saat paparan dan tidak hanya pada dosis janin diserap, seperti pada setiap bahan teratogen. Pada periode pra-implantasi embrio bersifat kurang radiosensitif, namun efek paparan radiasi lebih sering pada 14 hari pertama setelah pembuahan adalah kegagalan implantasi embrio (aborsi dini) atau tidak muncul efek sama sekali. Apabila anomali genetik atau malformasi terjadi, hasil yang dirasa mungkin adalah kehilangan embriopada periode tersebut atau perbaikan pada bagian embrio yang mengalami anomali dan sel-sel totipoten terbentuk pada tahap ini. Periode organogenesis, yaitu akhir minggu ke-2 hingga minggu ke-8 pasca-konsepsi, adalah periode yang sangat sensitif terhadap efek teratogenik radiasi pengion. Sel radiosensitif pada periode tersebut contohnya sel-sel sistem saraf pusat (SSP), meskipun periode pembentukan utamanya adalah antara minggu ke-8 dan 15 kehamilan yang merupakan periode sangat radiosensitif 15 .

Apabila sangat dibutuhkan pemeriksaan radiografi dari seorang wanita yang sedang hamil, maka paparan sinar-X akan diarahkan sebagian besar pada area kepala dan leher. Hal ini bertujuan untuk memenimalisir paparan pada janin, sehingga hanya sekitar
1 microgray ( $\mu \mathrm{Gy}$ ) saja yang diterima janin untuk pemeriksaan full mouth. Beberapa kemungkinan tentang hubungan serta pengaruh antara dosis radiasi kelenjar tiroid ibu dari pemeriksaan radiografi gigi dan bayi lahir dengan berat badan rendah mendorong ADA (American Dental Association) untuk merekomendasikan penggunaan kerah pelindung tiroid dan apron selama radiografi gigi, terutama anak-anak, perempuan usia subur, dan wanita hamil ${ }^{13}$.

\section{KESIMPULAN}

Radiasi sinar-x dental dimanfaatkan secara luas untuk menunjang penentuan diagnosis, prognosis dan rencana perawatan suatu kelainan rongga mulut. Akan tetapi, pemeriksaan tersebut tetap memiliki efek samping akibat proses ionisasi yang ditimbulkan sinar-x. Efek stokastik seringkali luput dari perhatian, karena kerusakan yang muncul tidak tampak secara lagsung seperti pada efek deterministik. Sekalipun kemunculan efek stokastik dipengaruhi oleh probabilitas pada tiap individu, perlu diingat bahwa efek ini tidak memerlukan ambang batas dosis. Dosis sekecil apapun dapat menimbulkan efek stokastik berupa mutasi pada tingkat genetik, serta keganasan pada tingkat somatik. Oleh karena itu, penerapan prinsip ALARA (As Low As Reasonably Achievable) serta proteksi yang baik pada pasien serta tenaga medis terkait sangat perlu diperhatikan. Proteksi dalam hal ini termasuk kontrol alat, perlindungan ruangan, kontrol dosis paparan komulatif, serta pemakaian apron sepanjang proses.

\section{DAFTAR PUSTAKA}


1. Ratnapalan S, Bentur Y, Koren G. 2008. Doctor, Will that X-ray Harm My Unborn Child. CMAJ 179 (2) : 1293-1296.

2. White SC, Pharoah MJ. 2009. Oral Radiology: Principles and Interpretation. 6th Ed. St. Louis: Mosby Elsevier. pp. 109-206.

3. Okano T, Sur J. 2009. Radiation Dose and Protection in Dentistry. JDSR 2010 (46) : 112-121.

4. Alatas Z. 2003. Efek Kesehatan Pajanan Radiasi Dosis Rendah. Seminar Aspek Keselamatan Radiasi dan Lingkungan pada Industri Non-Nuklir. BATAN: 28-38.

5. Ekayuda, I. 2005. Radioloogi Diagnostik. Edisi ke-2. Jakarta, Balai Penerbit FK UI. Hal. 15-17.

6. White SC, Mallya SM. 2012. Update on The Biological Effects of lonizing Radiation, Relative Dose Factors and Radiation Hygiene. Austral DJ (57) : 2-8.

7. ICRP, 2003. Biological Effects after Prenatal Irradiation (Embryo and Fetus). ICRP Publication 90. Ann. ICRP 33 (1-2).

8. Claus EB, Calvocoressi L, Bondy ML, Schildkraut JM, Wiemels JL, Wrensch M. 2012. Dental X-Rays and Risk of Meningioma. Cancer (September) : 4530-4536.

9. Whaites, E. 2007. Essential of Dental Radiography and Radiology. 4thEd. London: Churchill Livingstone Elsevier. pp. 97-204.

10. Cerqueira EM, Meireles JR, Lopes MA, Junqueira VC, Gomes-Filho IS, Trindade S, Machado-Santelli. 2008. genotoxic effects of X-rays on Keratinized Mucosa Cells during Panoramic Dental Radiography. DMJR 2008 (37) : 398-403.
11. Baskar, R. 2010. Emerging Role of Radiation Indued Bystander Effects : Cell Comunications and Carcinogenesis.

12. Coulthard P, Horner K, Sloan P, Theaker E. 2003. Master Dentistry: Oral and Maxillofacial Surgery, Radiology, Pathology and Oral Medicine. Churchill Livingstone. Pp: 247-250.

13. Wall BF, Mear JR, Muirhead CR. 2009. Protection of Pregnant Patients during Diagnostic Medical Exposures to lonising Radiation. Health Protection Agency (March): 6-10.

14. De Santis M, Cesari E, Nobili E, Straface G, Cavaliere AF, Caruso A. 2007. Radiation effect on development. Birth Defects Research (Part C) 81:177-182 (2007)

15. De Santis M, Di Gianantonio E, Straface G, Cavaliere AF, Caruso A, Schiavon F, Berletti R, Clementi. 2005. lonizing radiations in pregnancy and teratogenesis: A review of literature. Reproductive Toxicology 20 (2005) 323-329 